\title{
Fagopyrum urophyllum (Polygonaceae), a new record for India and notes on its typification
}

\author{
Das M. ${ }^{1}$ \& S.S. Dash ${ }^{2 \star}$ \\ ${ }^{1}$ Central National Herbarium, Botanical Survey of India, Howrah - 711 103, India \\ 'Botanical Survey of India, CGO Complex, Salt Lake, Kolkata - 700 064, India \\ *E-mail: ssdash2002@gmail.com
}

\begin{abstract}
Fagopyrum urophyllum (Bureau \& Franch.) H.Gross (Polygonaceae), is reported here as a new record to the Indian flora. The species, earlier known only from China, has been collected from the Namchi and Tendong region of the South district, Sikkim, India at an altitude of $1845 \mathrm{~m}$. A description along with illustration, photo plate of dissected flower parts, and a distribution map in India is provided herewith. Notes on the lectotypification of the name Fagopyrum urophyllum and a national conservation status of this species in India is also provided.
\end{abstract}

Keywords: Flora, Lectotype, New distribution, Polygonum, Sikkim, Tendong.

\section{Introduction}

The genus Fagopyrum Mill. (Polygonaceae) comprising of 28 species, is native of Indo-China to South Siberia (POWO, 2020). It is characterized by an ascending annual or perennial habit with deltoid to hastate leaves, oblique ochrea, heterostylous flowers and largely plaited cotyledons in the achenes (Dash, 1996). Hooker (1890) reported three species of Fagopyrum from the British India, while Steward (1930) reported four species from India. With regard to the Indian Himalayan region, four species viz., F. kashmirianum Munshi, F.cymosum (Trevir.) Meisn., F. esculentum Moench, F. tataricum (L.) Gaertn. have been reported (Dash, 1996, 2004; Srivastava, 2014; Sinha et al., 2019). Out of these, the latter three species are reported from

Received: 18.06.2021; Revised \& Accepted: 14.11.2021

Published Online: 31.12.2021
Sikkim Himalaya (Grierson \& Long, 1983; Dash, 2004).

As part of an ongoing taxonomic study of the family Polygonaceae in Eastern Himalaya, India, the authors collected flowering specimens of Fagopyrum from Namchi, South district, Sikkim in flowering condition. A critical examination of collected materials from field, study of the relevant literature (Hooker, 1890; Hara, 1966; Grierson \& Long, 1983; Dash, 1996, 2004; Sinha et al., 2019) and comparing the recent collected voucher specimens with earlier collected herbarium specimens housed at different herbaria (CAL, BSHC, ASSAM, ARUN, P, NY and K) the plant was identified as Fagopyrum urophyllum (Bureau \& Franch.) H.Gross which is hitherto unrecorded from India. A detailed description along with a colour photo plate, line drawings, locality map and field notes have been provided herewith.

\section{Materials and Methods}

Flowering specimens were collected from South district of Sikkim at an altitude range of 1800$1900 \mathrm{~m}$ during post monsoon and processed for the preparation of voucher specimens following a standard protocol (Jain \& Rao, 1977). Photographs were taken in the field with a HX $400 \mathrm{~V}$ camera (Sony, Tokyo, Japan). Flowers were dissected and observed under a SMZ1500 stereo microscope (Nikon, Tokyo, Japan) to study micromorphological characters. Earlier collections of the species lodged in Indian herbaria were also examined; the description was prepared based on the field observations and vouchers specimens. 
The current distribution status of Fagopyrum urophyllum in the Indian Himalayan region was assessed using the software ArcGIS 10.5 (ESRI, 2016). The geographical coordinates of each of the populations were collected with the help of a GPS (Garmin eTrex ${ }^{\circledR} 30 x$, Taiwan) during the survey. In view of the absence of any data on the population size of previous collected specimens from the Indian Himalayan region, only the latitude and longitude of the particular localities were considered to estimate the geographic range of this species. The software Conservation Assessment Tool (CAT) developed by the Royal Botanic Gardens, Kew, UK was used as an extension for ArcView 3.x, version 1.2, for estimating the extent of occurrence (EOO) and the area of occupancy (AOO) for a conservation assessment based on IUCN Categories and Criteria (2019).

\section{Taxonomic Treatment}

Fagopyrum urophyllum (Bureau \& Franch.) H.Gross, Bull. Géogr. Bot. 23: 21. 1913. Polygonum urophyllum Bureau \& Franch., J. Bot. (Morot) 5(10): 150. 1891.

Lectotype (designated here): CHINA, Se-tchuen (Sichuan) province, around Ta-Tsien-Lou, s.d., Prince Henri d'Orléans, collected during the trip of M. Bonvalot and Prince Henri d'Orléans (Voyage de M. Bonvalot et du Prince Henri d'Orléans à travers l'Asie), s.n. (P [P04963938 digital image!); isolecto P [P04963934 digital image!]).

Figs. 1 \& 2

Perennial undershrubs. Stems 60-90 cm long, simple, terete, sub-erect, brownish, much branched, 2-3 mm in diam., glabrous, finely striate, slightly woody; internodes $3.5-7 \mathrm{~cm}$ long, upper half of stems with shorter internode than lower half, reddish brown to green, finely pubescent at nodes. Ochrea membranous, tubular, 5-9 mm long, oblique at mouth, eciliate, prominently veined, glabrous, brown. Petioles 2-6 cm long, terete, densely pubescent, greenish. Leaves deltoid to hastate, $2-8 \times 1.5-4 \mathrm{~cm}$, broadly sagittate at base, margin entire, attenuate to long acuminate at apex (acumen 1-2 cm long), coriaceous; upper surface dark green, glaucescent, midrib prominent, minutely pubescent along veins, otherwise glabrous; lower surface light green, densely pubescent along veins, usually with whitish hair; lateral veins 6-7 pairs, palmately arranged; Inflorescence terminal, lax spreading branched panicles, 7-20 cm long; peduncle minutely pubescent, rarely glandular, 5-12 cm long; bracts greenish, narrowly funnel-shaped, 2-3 mm, apex acute to shortly acuminate, entire, glabrous, each 3 to 4-flowered. Pedicels 3-4 $\mathrm{mm}$ long, slender, glabrous, articulate at apex. Flower pentamerous, 2.5-4.5 mm long. Perianth lobes (tepals) 5, white, in two whorls, elliptic or elliptic-oblong, 2-3 × 1.5$2 \mathrm{~mm}$, obtuse at apex, margins entire, persistent. Stamens 8 , alternating with yellowish glandular discs; filaments unequal, 1.5-2 mm long, glabrous; anthers purple, $0.5-1 \mathrm{~mm}$ long, dorsifixed, dehiscence longitudinally. Ovary superior, trigonous, 0.5-0.8 mm long; styles 3, free, 0.7-1 $\mathrm{mm}$ long; stigmas capitate. Achenes broadly ovoid, abruptly trigonous, 3-4 × 1.5-2 mm, much exceeding or equalling the persistent perianth, black-brown, glabrous.

Flowering \& fruiting: Flowering from June to August; fruiting from July to November.

Habitat: Scatterley grows on gravelly hill slopes, forest margins, footpaths, brushes in valleys; at an elevation range of 1500-2200 m.

Distribution: INDIA: Namchi, Tendong Reserve, South district, Sikkim. CHINA: South and Central.

Specimens examined: INDIA, Sikkim, South district, near Namchi, N $27^{\circ} 9257.543$, E $88^{\circ} 2228.463$, 1848.5 m, 24.10.2020, M.Das E S.S.Dash 84754 (CAL); Ibid., N $27^{\circ} 92$ 26.13, E $88^{\circ} 252$ 133, 1801 m, 24.10.2020, M.Das \& S.S.Dash 84758; near Tendong, N 27²2 6.623, E $88^{\circ} 232$ 463, 1785 m, 24.10.2020, M.Das E S.S.Dash 84755 (CAL); Namchi, 06.08.2000, B.K.Shukla 23548; Ibid., 06.08.2000, B.K.Shukla 23540; Tendong R.F., 17.08.1985, A.K.Verma 3785 (BSHC).

Conservation status: During our studies, we were able to locate eight populations of Fagopyrum 

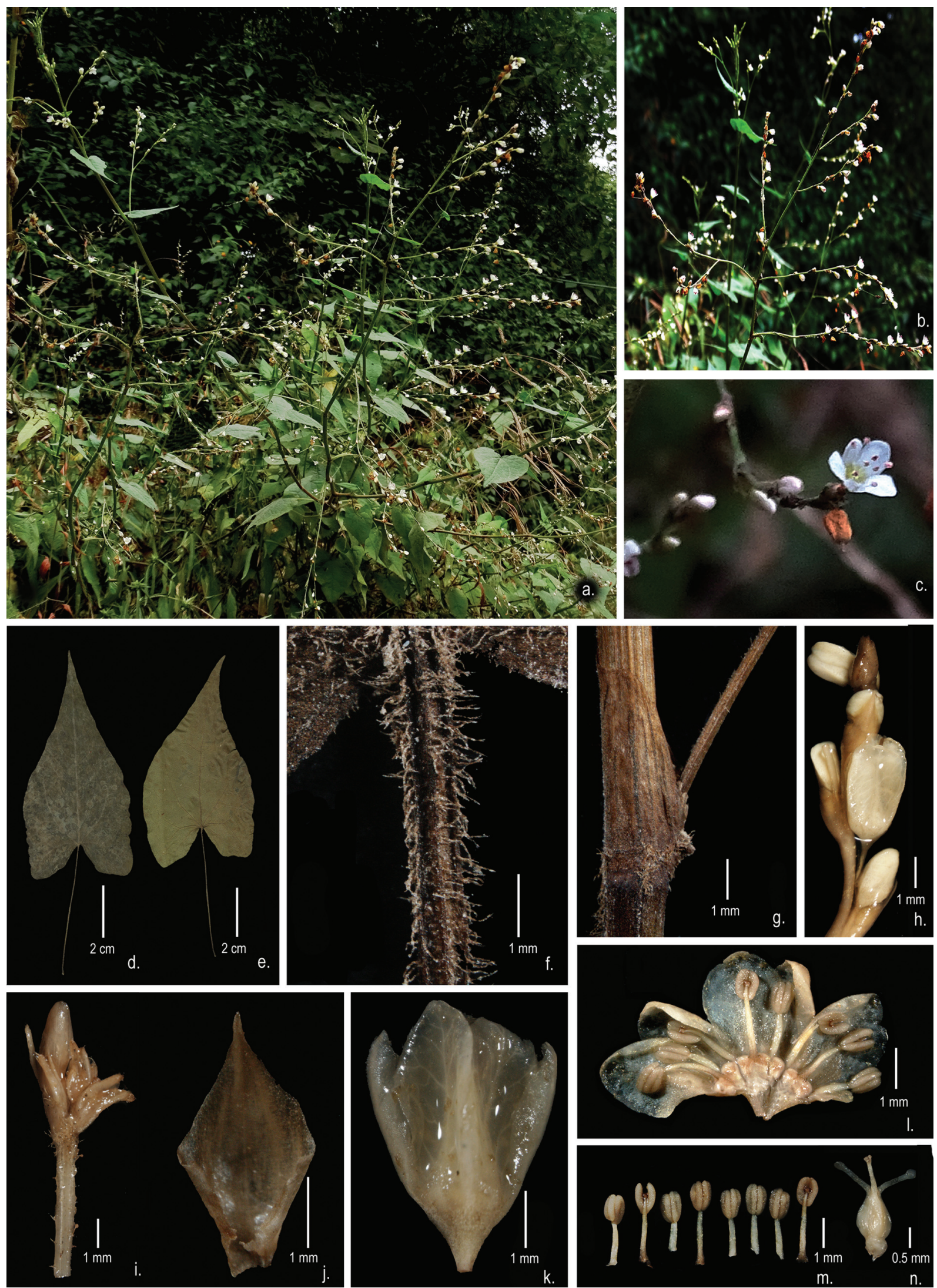

Fig. 1. Fagopyrum urophyllum (Bureau \& Franch.) H. Gross a. Habit; b. Inflorescence; $\boldsymbol{c}$. Flower; d. Adaxial surface of leaf; e. Abaxial surface of leaf; f. Petiole; g. Ochrea; h. Flower twig; i. Peduncle; j. Bract: adaxial surface; k. Flower; I. Tepal split open; m. Stamens; n. Pistil (photos by Monalisa Das). 


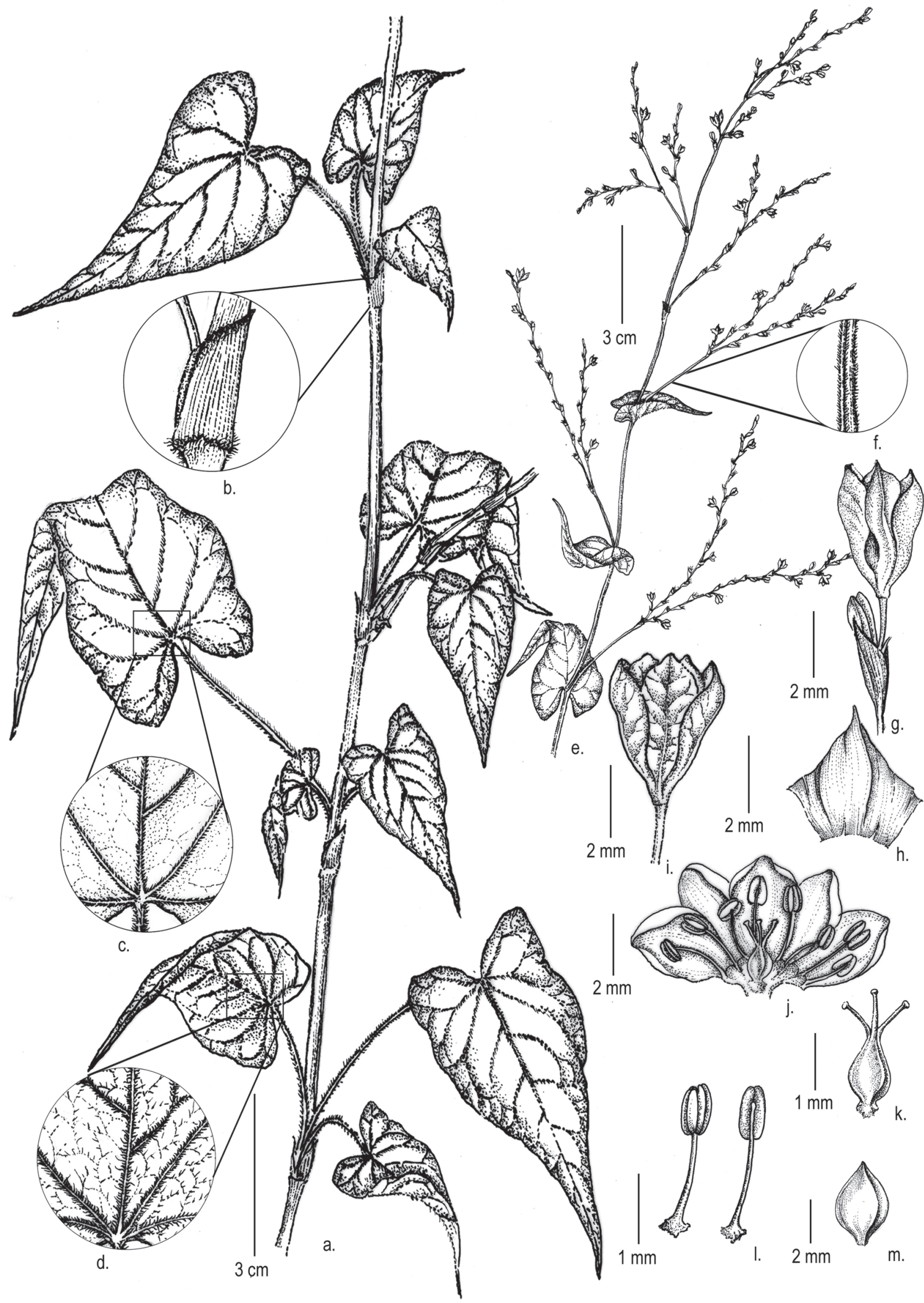

Fig. 2. Fagopyrum urophyllum (Bureau \& Franch.) H.Gross: a. Habit; b. Enlarged view of ochrea; c. Enlarged view of adaxial leaf surface; d. Enlarged view of abaxial leaf surface; e. Inflorescence; f. Enlarge view of Peduncle surface; g. Flower twig; h. Bract: abaxial surface; i. Flower; j. Tepal split open; k. Pistil; I. Stamens; m. Achene (drawn by Monalisa Das). 

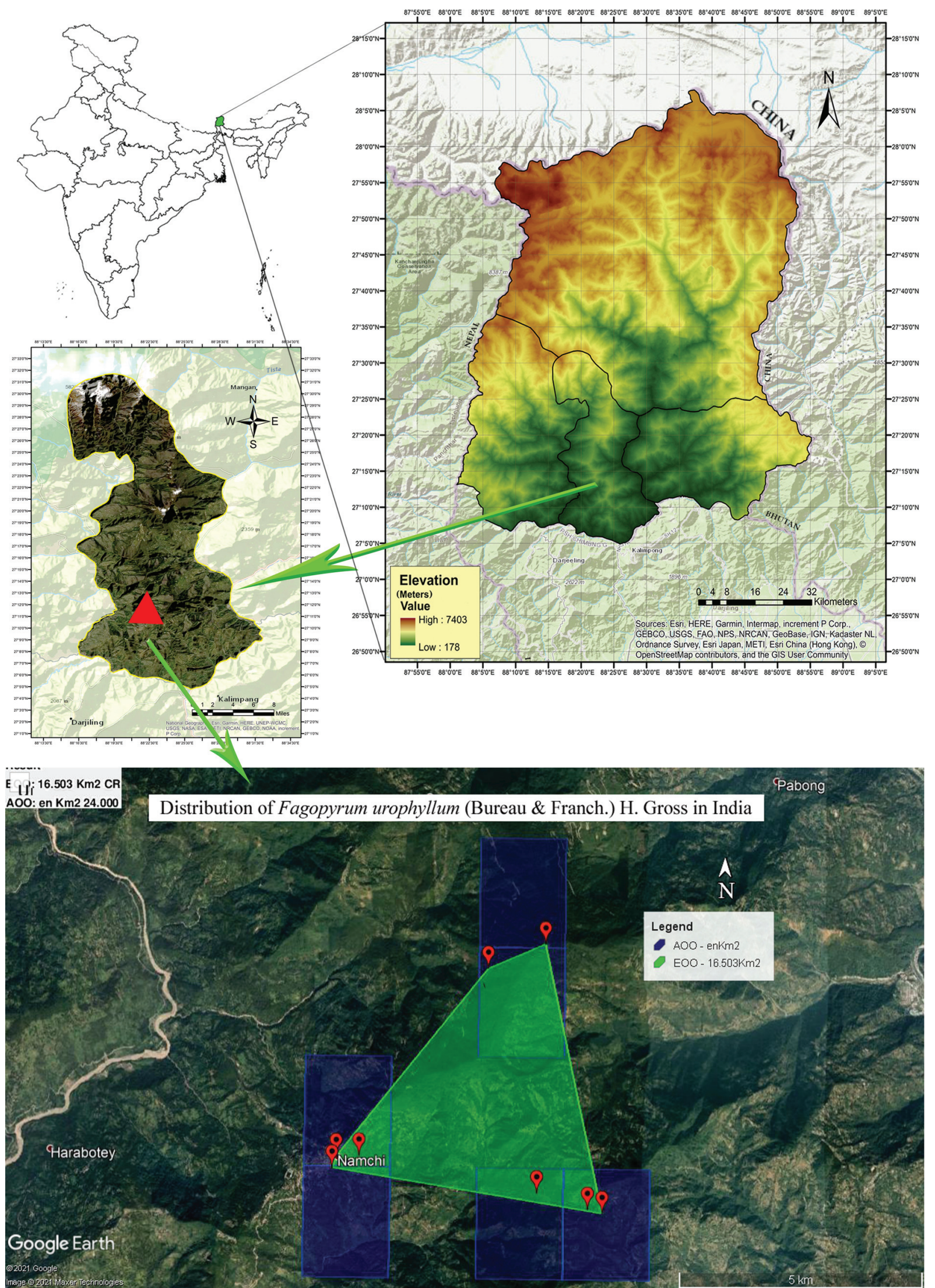

Fig. 3. Locality maps and current distribution status of Fagopyrum urophyllum (Bureau \& Franch.) H.Gross, near Namchi, Sikkim, South district, India. 
urophyllum in Namchi South district, Sikkim and its surrounding areas (GPS coordinates: $\mathrm{N} 27^{\circ} 92$ 57.543, E $88^{\circ} 222$ 8.463; N $27^{\circ} 1226.623$, E $88^{\circ} 232$ 463; N $27^{\circ} 92$ 26.13, E $88^{\circ} 252$ 133; N 27 92 28.633, E $88^{\circ} 25223$; N $27^{\circ} 9254.133$, E $88^{\circ} 212$ 513; N $27^{\circ} 9239.13$, E $88^{\circ} 242$ 243; N $27^{\circ} 102$ 1.763, E $88^{\circ} 212$ 543; N $27^{\circ} 12223.243$, E $88^{\circ} 242$ 28.913.) (Fig. 3). Each population consisted of 510 mature plants in various flowering stages. According to the GPS coordinates, the extent of occurrence (EOO) of the species F. urophyllum was calculated to be $16.5 \mathrm{~km}^{2}$, and the area of occupancy (AOO) $24 \mathrm{~km}^{2}$. While calculating the EOO and AOO we have also taken into consideration earlier collections. The species is dwindling in its natural habitat due to severe habitat fragmentation and vulnerable because of its low density of adult plants.

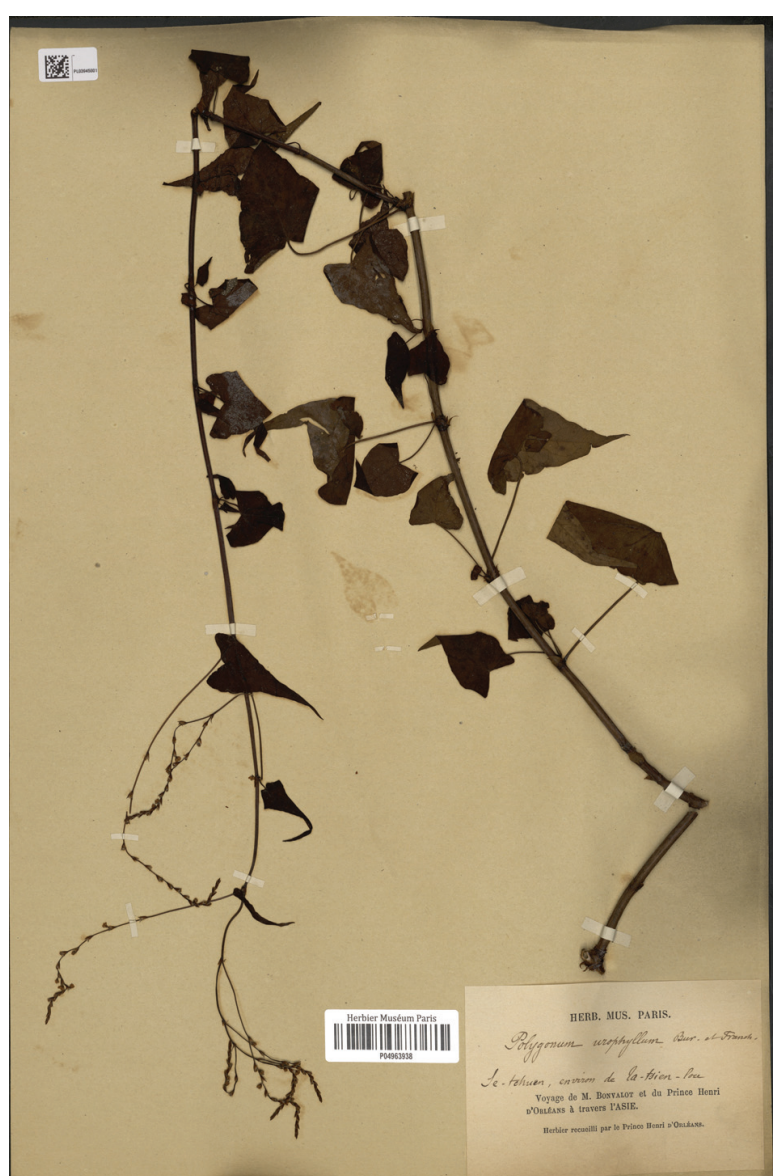

Fig. 4. Lectotype of Polygonum urophyllum Bureau \& Franch (P04963938). http://coldb.mnhn.fr/catalognumber/mnhn/p/ p04963938 (C) Muséum National d'Histoire Naturelle, Paris, France, Collection: Vascular plants (P), Specimen P04963938, Reproduced with permission.
Moreover, the natural habitats of the species are under continuous pressure from various developmental activities in the region, such as road construction, Building construction etc. Other possible threats are land clearance for agriculture expansion, high grazing and forest fires. Since no data on the population sizes of previous collections were available, we only used the geographic coordinates of the collected localities to estimate the geographic range of this species (Moat, 2007) through the Conservation Assessment Tool GeoCAT. With the currently available information, the threat status for Fagopyrum urophyllum in India has been assessed as 'Critically Endangered' [CR B1 ab(iii)+2ab(iii);].

Notes: This species was initially placed in section Tiniaria of genus Fagopyrum (Gross, 1913), but later Steward (1930) treated it under section Fagopyrum of genus Polygonum. Haraldson (1978) elevated section Fagopyrum to generic rank. The species also shows similarity in leaf characteristics with Fallopia convolvulus (L.) Love. Fagopyrum urophyllum can be easily differentiated from its allied species by its shrubby habit, broadly sagittate leaves with long acuminate or caudate apex.

\section{Lectotypification}

Bureau and Franchet (1891), while describing Polygonum urophyllum provided for their collection of specimens from China only the locality information, Sichuan province, around Ta-TsienLou in 1890 during a trip of M. Bonvalot and Prince Henri d'Orléans. Gross (1913), while transferring the species to Fagopyrum, did not indicate any original collection. Therefore, the species name requires lectotypification. We traced two specimens with locality given as: "Chine, province du Setchuen, autour de Ta-tsien-lou” at P (Museum National d'Histoire Naturelle, Paris) with barcodes P04963934 and P04963938 (digital images!).

The sheet P04963938 (digital image!) bears all the characteristics mentioned in the protologue and is well preserved. Hence, the material, P04963938 has been selected here as the lectotype of the name 
Polygonum urophyllum (basionym of Fagopyrum urophyllum) as per Art. 9.3 of the ICN (Turland et al., 2018).

\section{Acknowledgments}

Authors are thankful to Director, Botanical Survey of India, Kolkata for providing necessary research facility; Principal Chief Conservator of Forests, Department of Forest, Govt. of Sikkim for giving permission and logistic support. We express our sincere gratitude to the Curators of CAL, BSHC, ASSAM, ARUN, P and NY for their invaluable help in locating type specimens.

\section{Literature Cited}

BUREAU MM. Ed. \& A. FRANCHET 1891. Plantes nouvelles du Thibet et de la Chine occidentale: recueillies pendant le voyage de M. Bovalot et du Prince Henri d'Orléans en 1890. Journal de Botanique 5(10): 149-160.

DASH S.S. 1996. Distribution and diversity of Polygonaceae in Sikkim. Journal of Hill Research 9(2): 380-394.

DASH S.S. 2004. Systematic studies in Polygonum sensu lato of Sikkim. Journal of Economic and Taxonomic Botany 28(1): 129-164.

ESRI 2016. ArcGis Desktop: Release 10.5. Redlands: Environmental Systems Research Institute.

GRIERSON A.J.C. \& D.G. LONG 1983. Flora of Bhutan including a record of plants from Sikkim. Volume 1(1). Royal Botanic Garden Edinburgh, London.

GROSS H. 1913. Beiträge zur Kenntnis der Polygonaceen. Botanische Jahrbucher fur Systematik, Pflanzengeschichte und Pflanzengeographie. 49: 234-339.

HARA H. 1966. The flora of eastern Himalaya. University of Tokyo Press, Tokyo.
HARALDSON K. 1978. Anatomy and taxonomy in Polygonaceae subfam. Polygonoideae Meisn. emend. Jaretzky. Symbolae Botanicae Upsalienses. 22: 1-95.

HOOKER J.D. 1890. The Flora of British India. Volume 5. L. Reeve \& Co. London.

IUCN 2019. Guidelines for using the IUCN Red List Categories and Criteria. Version 14. Prepared by the Standards and Petitions Committee. Available at: http:/ /www.iucnredlist.org/documents/RedListGuidelines.

JAIN S.K. \& R.R. RAO 1977. A handbook of field and herbarium methods. Today and Tomorrow's Printers and Publishers, New Delhi.

MOAT J. 2007. Conservation assessment tools extension for ArcView 3.x, version 1.2. GIS Unit, Royal Botanic Gardens, Kew. http://www.rbgkew.org.uk/gis/cats.

POWO 2020. Plants of the World Online. Facilitated by the Royal Botanic Gardens, Kew. Available at: http:// plantsoftheworldonline.org/ (Accessed on 20.03.2021).

SINHA B.K, DASH S. S. \& P. SINGH 2019. Plants of Indian Himalayan Region (An Annotated Checklist \& Pictorial Guide) Part II.Botanical Survey of India, Kolkata.

SRIVASTAVA R.C. 2014. Family Polygonaceae in India. Indian Journal of Plant Sciences 3(2): 112-150.

STEWARD A. N. 1930. The Polygonaceae of eastern Asia. Contributions from the Gray Herbarium of Harvard University 5(88): 1-129.

TURLAND N.J., WIERSEMA J.H., BARRIE F.R., GREUTER W., HAWKSWORTH D.L., HERENDEEN P.S., KNAPP S., KUSBER W.H., LI D.Z., MARHOLD K., MAY T.W., MCNEILL J., MONRO A.M., PRADO J., PRICE M.J. \& G.F. SMITH (eds.) 2018. International Code of Nomenclature for Algae, Fungi, and Plants (Shenzhen Code) adopted by the Nineteenth International Botanical Congress Shenzhen, China, July 2017. Regnum Vegetabile 159. Volume 38. Koeltz Botanical Books, Glashütten. https://doi.org/ 10.12705/Code. 2018 